\title{
Influence of Reproduction on Stable-Isotope Ratios: Nitrogen and Carbon Isotope Discrimination between Mothers, Fetuses, and Milk in the Fin Whale, a Capital Breeder
}

\author{
A. Borrell ${ }^{\star}$ \\ E. Gómez-Campos \\ A. Aguilar \\ Biodiversity Research Institute (IRBio) and Department of \\ Animal Biology, Faculty of Biology, University of Barcelona, \\ 08028 Barcelona, Spain
}

Accepted 10/29/2015; Electronically Published 12/2/2015

\begin{abstract}
In mammals, the influence of gestation and lactation on the tissue stable-isotope ratios of females, fetuses, and milk remains poorly understood. Here we investigate the incidence of these events on $\delta^{13} \mathrm{C}$ and $\delta^{15} \mathrm{~N}$ values in fin whales sampled off northwestern Spain between 1983 and 1985. The effect of gestation on tissue stable-isotope ratios was examined in the muscle of pregnant females $(n=13)$ and their fetuses $(n=10)$ and that of lactation in the muscle of nursing females $(n=21)$ and their milk $(n=25)$. Results suggest that fetuses are enriched compared to their mothers in both ${ }^{15} \mathrm{~N}\left(\Delta^{15} \mathrm{~N}=1.5 \%\right.$ ) and ${ }^{13} \mathrm{C}$ $\left(\Delta^{13} \mathrm{C}=1.1 \%\right.$ ), while, compared to muscle, milk is enriched in ${ }^{15} \mathrm{~N}\left(\Delta^{15} \mathrm{~N}=0.3 \%\right.$ ) but depleted in ${ }^{13} \mathrm{C}\left(\Delta^{13} \mathrm{C}=-0.62 \%\right)$. This pattern is consistent with that previously observed for other species that, like the fin whale, rely on endogenous energy during reproduction, and it substantiates a general difference in the physiological processing of nitrogen and carbon balances between income and capital breeders. These findings are relevant to the understanding of the energetic balance of mammals during gestation and lactation and are central when inferences on trophic ecology are drawn from isotopic values of reproductive females.
\end{abstract}

Keywords: nutritive condition, reproductive state, fin whale, stable isotopes, fetus, milk, $\delta^{15} \mathrm{~N}, \delta^{13} \mathrm{C}$.

*Corresponding author; e-mail: xonborrell@ub.edu.

Physiological and Biochemical Zoology 89(1):41-50. 2016. (C) 2015 by The University of Chicago. All rights reserved. 1522-2152/2016/8901-5017\$15.00. DOI: $10.1086 / 684632$

\section{Introduction}

The stable-isotope ratios of carbon $\left(\delta^{13} \mathrm{C}\right)$ and nitrogen $\left(\delta^{15} \mathrm{~N}\right)$ have been widely used to study diet, trophic interactions, migratory patterns, and habitat use in mammals and other vertebrates (e.g., Kelly 2000; Koch 2007; Ben-David and Flaherty 2012; Borrell et al. 2013; Giménez et al. 2013). However, the mechanisms determining incorporation rates of stable isotopes in tissues and their discrimination factors still remain poorly understood. Potential elements affecting discrimination include taxon, growth rate, type of tissue, nutritional or reproductive status, reproductive strategy, differences in digestive physiology, the means of voiding nitrogenous waste, the macromolecular composition of sources (i.e., proportions of protein, carbohydrate, and lipid), and the extent and type of metabolic routing that dietary macromolecules undergo before integrating into tissues (i.e., from dietary protein to body protein or from dietary fat to body fat; Caut et al. 2009; Borrell et al. 2012; Kurle et al. 2014). In birds, the isotopic discrimination occurring during reproduction has received attention, and differences have been observed between capital breeders, which rely on endogenous reserves, and income breeders, which rely on recently acquired nutrients (e.g., Klaassen et al. 2001; Gauthier et al. 2003; Hobson 2006; Langin et al. 2006; Bond et al. 2007).

In mammals, nutritional stress and reproduction have been identified as significant events affecting the isotopic signal and thus interfering with interpretation of ecological traits (Koch 2007). A focus of interest has been the isotopic discrimination between the reproducing female and her nursing young, and results commonly show increased $\delta^{15} \mathrm{~N}$ values in the latter because they obtain nourishment from their mothers, thus establishing a parallelism with a trophic relation (e.g., Fogel et al. 1989; Hobson et al. 1997, 2000; Hobson and Sease 1998; Cherel et al. 2015). In contrast, variation in $\delta^{13} \mathrm{C}$ values does not show a clear-cut pattern, and nursing young show very variable values, depending on the composition of the milk they ingest.

This is likely due to the variability of carbon sources that can be used to build protein in the nursing young. If it originates only from the protein fraction of the milk, then the $\delta^{13} \mathrm{C}$ values are unlikely to be changed. However, if it originates from the lipid fraction, $\delta^{13} \mathrm{C}$ values of protein in the nursing young will be lower than those in the mother, because lipids are ${ }^{13} \mathrm{C}$ depleted relative to proteins (DeNiro and Epstein 1977). The latter possibility appears to be substantiated by the findings of Jenkins et al. (2001), who found that $\delta^{13} \mathrm{C}$ values in bulk milk and in nursing young plasma were correlated. Milk lipids can be used both for energy metabolism and for protein synthesis, and 
therefore the lipid content of the milk may be critical in determining the use of the lipid carbon structure. When milk lipid content is high, a larger relative fraction of those lipids may be used to build protein and $\delta^{13} \mathrm{C}$ values would tend to be lower, but the opposite will happen when milk lipid content is low.

Some studies have focused on the estimation of the time required after weaning for reducing such discrimination value (Jenkins et al. 2001; Newsome et al. 2006; Dalerum et al. 2007). However, the overall pattern of variation of stable-isotope ratios in the tissues of mammalian females when going through reproduction still remains to be properly understood (Koch 2007; Habran et al. 2010).

Cetaceans are an animal group in which the use of stable isotopes has received particular attention because these animals are difficult to observe in the wild, live in inaccessible oceanic habitats, are extremely mobile, and undergo long migrations. In this scenario, stable isotopes are often among the only means to obtain critical information on ecology or behavior (Newsome et al. 2010). However, these traits of the group, added to the insurmountable logistical difficulties of keeping most species in captivity, have hindered the experimental studies necessary to master the sources of intrapopulation variation and to understand the physiological processes that influence stable-isotope values of individuals. This is particularly true in mysticetes, a group in which studies relating stable-isotope values to reproductive biology appear to be nonexistent, despite the impact of reproduction on the body energy stores, and the associated mobilization of lipids and proteins is particularly significant because they are capital breeders (Festa-Bianchet et al. 1998). In certain tissues, the physiological dynamism implies an agile turnover that is likely to affect stable-isotope values and in this way complicate the use of these tracers in ecological assessment. Thus, in terrestrial mammals, nutritional stress often increases $\delta^{15} \mathrm{~N}$ values when nitrogen balance falls into negative values (Fuller et al. 2004; Voigt and Matt 2004), while gestation decreases this ratio when pregnant females attain a positive nitrogen balance (Kurle 2002; Fuller et al. 2004). Conversely, the limitation of excretion in fasting marine mammals without access to fresh water appears to interfere with some of these patterns and to limit the rise in $\delta^{15} \mathrm{~N}$ values (Polischuk et al. 2001; Aguilar et al. 2014; Vales et al. 2015), thus highlighting the need to fully understand the impact of these physiological processes on stable-isotope profiles to permit informed interpretation within the context of feeding ecology.

Fin whales (Balaenoptera physalus) are a representative model of the mysticete taxon. Like most other baleen whales, they are migratory animals that spend the summer in feeding grounds located at high latitudes, where food is abundant, and move in the winter to lower latitudes, where food is scarce. As a consequence of these movements, they experience a remarkable feeding seasonality that forces periodical reliance on accumulated body reserves (Aguilar 2009). Superimposed on this regime, reproduction adjusts to a 2 -yr cycle. In the middle of the first winter females become pregnant, and soon afterward they start the journey to the feeding grounds. After a period of intensive feeding that lasts the complete summer, they return to the wintering grounds to give birth. Lactation lasts about 7 mo and begins while the female is still at low latitudes, it continues during the poleward migration, and finishes soon after the mother and the calf have reached the feeding ground early in the following summer. This cycle implies that lactating females have to defray the energetic taxation of lactation and migration mostly during the period of low food consumption (Lockyer 1981, 1984; Aguilar 2009). Because this animal is a capital breeder, the energy and protein requirements to cover that expenditure are supplied by body reserves stored during the previous feeding season; thus, it is estimated that the cost of milk production alone represents $25 \%$ of the proteins and $30 \%$ of the lipids that constitute the maternal body (Oftedal 2000). To this it should be added that the fin whale is particularly suitable as a model for testing hypotheses on physiological processing of stable isotopes because most of its populations base their diet on a single resource, the planktonic euphausiids known as krill, a fact that avoids the incidence of potentially confounding changes in diet (Borrell et al. 2012).

Here we investigate the effect of reproduction on $\delta^{13} \mathrm{C}$ and $\delta^{15} \mathrm{~N}$ values in fin whales, taking advantage of a comprehensive tissue sample collection available from the northwestern coast of Spain, a feeding area for one of the stocks of the eastern North Atlantic population of the species. The specific objectives of this study were to assess (1) the isotopic discrimination between mothers and their fetuses and milk, (2) the isotopic differences between pregnant and lactating females, and (3) the potential differences between the patterns observed in this species and those in other species previously studied, to gain an insight into the effect of different breeding strategies on stable-isotope discrimination.

\section{Material and Methods}

The tissue samples of fin whales studied here were obtained from the routine sampling that was conducted at the Caneliñas whaling station during the whaling seasons of 1983-1985 with the objective of general monitoring of the population exploited. The factory was situated on the northwestern coast of Spain, and whales brought and flensed there had been taken in the whaling grounds located at $40^{\circ}-45^{\circ} \mathrm{N}$ and $8^{\circ}-11^{\circ} \mathrm{W}$ (Sanpera and Aguilar 1992).

The tissues analyzed were muscle and milk. The set of individuals sampled included 13 pregnant females and their fetuses (although a fetus sample was unavailable from 3 females) and 25 lactating females (although the muscle was unavailable from 4 of them). Gestation was established by the presence of a fetus in the uterus and lactation by the presence of milk in the mammary glands. The muscle samples were collected from the region posterior to the dorsal fin, wrapped in aluminium foil, and preserved inside a labeled plastic bag. The milk samples were collected from the contents of the lactiferous ducts after sectioning of the gland and were preserved in labeled glass containers. All samples were preserved at $-20^{\circ} \mathrm{C}$ until analysis.

Before analysis, the muscle tissue $(1 \mathrm{~g})$ was dried over $3 \mathrm{~d}$ at $70^{\circ} \mathrm{C}$ and ground to powder with mortar and pestle. Because lipids 
confound the analyses by decreasing the $\delta^{13} \mathrm{C}$ value (DeNiro and Epstein 1977), they were removed from the samples by rinsing the ground tissue several times with a $2: 1$ chloroform:methanol mixture, following the Folch method (Folch et al. 1957). In the case of milk, proteins and lipids were separated and processed independently with procedures similar to those for muscle.

Weighed subsamples (approx. $0.5 \mathrm{mg}$ ) of the powdered sample were placed in tin buckets and crimped for combustion. Isotope analyses were carried out by means of elemental analysisisotope ratio mass spectrometry with a Thermo Finnigan Flash 1112 elemental analyzer (CE Elantech, Lakewood, NJ) coupled to a Delta $\mathrm{C}$ isotope ratio mass spectrometer via a ConFlo III interface (Thermo Finnigan MAT, Bremen, Germany).

The results were presented according to the $\delta$ notation, where the relative variation from predefined standards of stable-isotope ratios is expressed in parts per thousand. This variation is calculated as

$$
\delta R=\left(\frac{\mathrm{RS}}{\mathrm{RR}}-1\right) \times 1,000,
$$

where RS is the ratio of the heavy isotope to the light isotope in the sample and RR is the ratio of the heavy isotope to the light isotope in the reference.

The R standards for ${ }^{13} \mathrm{C}$ and ${ }^{15} \mathrm{~N}$ are the Vienna Peedee Belemnite (V-PDB) standard and atmospheric nitrogen (air), respectively. The international isotope secondary standards of known ${ }^{13} \mathrm{C} /{ }^{12} \mathrm{C}$ ratios in relation to $\mathrm{V}$-PDB, namely, polyethylene (IAEA$\mathrm{CH}_{7}, \delta^{13} \mathrm{C}=-31.8 \%$ ), graphite (USGS24, $\delta^{13} \mathrm{C}=-16.1 \%$ ), and sucrose (IAEA- $\mathrm{CH}_{6}, \delta^{13} \mathrm{C}=-10.4 \%$ ), were used for the calibration of $\delta^{13} \mathrm{C}$ to a precision of $0.2 \%$. For nitrogen, the international isotope secondary standards of known ${ }^{15} \mathrm{~N} /{ }^{14} \mathrm{~N}$ ratios in relation to air, namely, ammonium sulphate (IAEA-N-1, $\delta^{15} \mathrm{~N}=+0.4 \%$; and IAEA-N-2, $\delta^{15} \mathrm{~N}=+20.3 \%$ ) and potassium nitrate (IAEA- $\mathrm{NO}_{3}, \delta^{15} \mathrm{~N}=+4.7 \%$ ), were used for the calibration of $\delta^{15} \mathrm{~N}$ to a precision of $0.3 \%$.

The reference materials used for the analysis are distributed by the International Atomic Energy Agency (IAEA). The analyses were carried out in the Centres Científics i Tecnològics of the University of Barcelona (CCiT-UB).

The normality and homoscedasticity of the data were tested with Lilliefors's and Levene's tests, respectively. Pairwise Student's $t$-tests were performed to compare $\delta^{15} \mathrm{~N}$ and $\delta^{13} \mathrm{C}$ between mothers and their respective fetuses $(n=10)$ and between lactating females and their respective milk samples (proteins and lipids; $n=17$ ). Differences between $\delta^{15} \mathrm{~N}$ and $\delta^{13} \mathrm{C}$ in lactating and pregnant females were analyzed with Student's $t$-tests. All statistical analyses were conducted with the SPSS 15 software package.

\section{Results}

A summary of the $\delta^{15} \mathrm{~N}$ and $\delta^{13} \mathrm{C}$ data for the muscle of $34 \mathrm{fe}$ males, split by their reproductive states, and for 10 fetus and 25 milk samples (proteins and lipids split), is shown in table 1 and figure 1. Milk contained $60.1 \% \pm 10 \%$ (mean $\pm \mathrm{SD}, n=$ 6) lipids.
Table 1: $\delta^{13} \mathrm{C}$ and $\delta^{15} \mathrm{~N}$ values for each sample group and the significance of the comparison tests carried out between them

\begin{tabular}{|c|c|c|c|}
\hline & $n$ & $\delta^{13} \mathrm{C}$ & $\delta^{15} \mathrm{~N}$ \\
\hline \multicolumn{4}{|l|}{$\begin{array}{l}\text { Isotope values } \\
\qquad(\text { mean } \pm \mathrm{SD}, \% \mathrm{o})\end{array}$} \\
\hline Fetuses & 10 & $-17.45 \pm .53$ & $11.46 \pm .38$ \\
\hline Pregnant females & 13 & $-18.64 \pm .45$ & $9.82 \pm .59$ \\
\hline Lactating females & 21 & $-18.06 \pm .22$ & $9.46 \pm .55$ \\
\hline Milk proteins & 25 & $-18.69 \pm .85$ & $9.79 \pm .37$ \\
\hline Milk lipids & 25 & $-24.92 \pm .91$ & $\ldots$ \\
\hline \multicolumn{3}{|l|}{ Pair comparisons $(P)$ : } & \\
\hline females & $\cdots$ & $<.001$ & $<.001$ \\
\hline $\begin{array}{l}\text { Milk proteins- } \\
\text { lactating females }\end{array}$ & $\cdots$ & .013 & .023 \\
\hline $\begin{array}{l}\text { Milk lipids- } \\
\text { lactating females }\end{array}$ & $\cdots$ & .001 & $\cdots$ \\
\hline $\begin{array}{l}\text { Pregnant-females- } \\
\text { lactating females }\end{array}$ & $\ldots$ & $<.001$ & .08 \\
\hline
\end{tabular}

Results from pairwise Student's $t$-tests between fetuses and their mothers showed a highly significant difference $(n=10$; $\left.\delta^{15} \mathrm{~N}: t=-6.465, P<0.001 ; \delta^{13} \mathrm{C}: t=-2.364, P<0.001\right) . \mathrm{Fe}-$ tuses showed $1.5 \%$ o $\pm 0.44 \%$ higher $\delta^{15} \mathrm{~N}$ values and $1.12 \%$ o \pm $0.66 \%$ o higher $\delta^{13} \mathrm{C}$ values, as compared to their mothers (fig. 2).

Results from pairwise Student's $t$-tests showed higher $\delta^{15} \mathrm{~N}$ $(0.3 \%$ o $\pm 0.49 \%$ o $)$ and lower $\delta^{13} \mathrm{C}(0.62 \%$ o $\pm 0.93 \%$ o values in the milk proteins than in the muscle of the respective lactating females $\left(n=17 ; P\left(\delta^{15} \mathrm{~N}\right)=0.023, P\left(\delta^{13} \mathrm{C}\right)=0.013\right.$; fig. 3). Milk lipids showed lower $\delta^{13} \mathrm{C}(6.7 \%$ o $\pm 1.1 \%$ o $)$ values than did the muscle of the respective lactating females $\left(n=17 ; P\left(\delta^{15} \mathrm{~N}\right.\right.$ and $\left.\delta^{13} \mathrm{C}\right)<0.001$; fig. 3).

Results from the Student's $t$-tests between the muscle of pregnant $(n=13)$ and lactating $(n=21)$ females showed a significant difference in $\delta^{13} \mathrm{C}(t=-4.2, P<0.001)$ and no difference in $\delta^{15} \mathrm{~N}(t=1.82, P=0.08)$. In the latter case, however, the $P$ value was on the verge of significance $(P<0.1)$, suggesting that $\delta^{15} \mathrm{~N}$ values in the muscle of lactating females might indeed be lower than those in pregnant females.

\section{Discussion}

\section{Isotopic Discrimination between Mother and Fetus}

Few previous studies on stable isotopes in mammals include fetal tissues, and even fewer include concomitantly the tissues of their mothers to allow mother-fetus comparison. When this comparison is made, the results are very variable between species, a fact that has led researchers to attribute the observed differences to naturally existing species-specific variability that occurs without a generalized pattern (e.g., Jenkins et al. 2001). However, when the collective results of these studies are examined in detail (table 2), they do show a pattern apparently driven by the strategy of use of body stores during breeding, that is, a difference between income breeders - species that sustain 


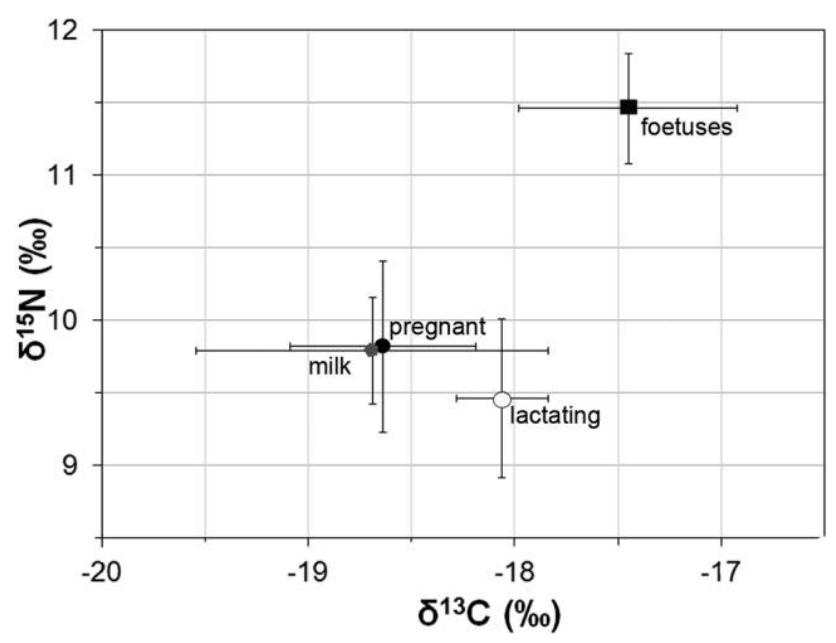

Figure $1 . \delta^{13} \mathrm{C}$ and $\delta^{15} \mathrm{~N}$ values (mean $\pm 1 \mathrm{SD}$ ) found in the muscle of North Atlantic fin whale females in various reproductive conditions, as well as in the milk protein of lactating females. A color version of this figure is available online.

reproduction with ingested nutrients - and capital breedersspecies that sustain reproduction with previously stored body reserves because ingestion of food during reproduction is insufficient to ensure offspring development (Stephens et al. 2009).

Thus, with regard to $\delta^{15} \mathrm{~N}$ discrimination (hereafter $\Delta^{15} \mathrm{~N}$ ) between maternal and fetal tissues, in income breeders it is usually nonexistent. Such results were found by Fogel et al. (1989) in humans through the comparison of fingernails grown during gestation in neonates and their mothers. Similar results were found by Jenkins et al. (2001) in nine income-breeder mammals (moose Alces alces, black-tailed deer Odocoileus hemionus, coyote Canis latrans, domestic rabbit Oryctolagus caniculus, rat Rattus norvegicus, cow Bos taurus, sheep Ovis aries, pig Sus scrofa, and cat Felis catus) through the comparison of values in red blood cells (RBCs) of mothers and their neonates sampled 12-14 d postpartum. The latter are considered to still reflect gestational values because the half-life of RBCs is estimated to be at least several weeks (e.g., in bears it is $28 \mathrm{~d}$; Hilderbrand et al. 1996).

Contrary to this, in capital breeders $\Delta^{15} \mathrm{~N}$ values between maternal and fetal tissues showed positive figures in all cases. Thus, Jenkins et al. (2001), studying the grizzly bear (Ursus arctos), and Barboza and Parker (2008), studying the reindeer (Rangifer tarandus), found, respectively, $\Delta^{15} \mathrm{~N}$ neonatal/maternal values of $1.7 \%$ and $1.2 \%$ in the RBCs; and Habran et al. (2010), studying the northern elephant seal (Mirounga angustirostris), found $\Delta^{15} \mathrm{~N}$ of $0.6 \%$ in RBCs from 5-d pups, as compared to RBCs of their mothers. Also, Nelson et al. (1998) studied collagen from fossil bones of the European cave bear (Ursus spelaeus) and found that $\Delta^{15} \mathrm{~N}$ between neonates or fetuses and adults was $5 \%$, although these results should be examined with caution because the material analyzed was about 48,000 yr old and the samples from neonates or fetuses and those from adults were not paired. Our results, the first of this nature to be obtained in a cetacean, are consistent with this pattern by showing a fetal-maternal $\Delta^{15} \mathrm{~N}$ in muscle of $1.5 \%$.
The observed differences in fetal-maternal $\Delta^{15} \mathrm{~N}$ between income and capital breeders are likely related to the way each group manages their reserves of energy and protein. As opposed to income breeders, which directly use ingested nutrients to build the tissues of their fetuses, female capital breeders rely on the nutrients stored in their own bodies to ensure the growth of the fetuses, because they do not ingest sufficient food during the gestation period (Stephens et al. 2009). Thus, bears have a long hibernation, during which they are not able to feed, and this overlaps their main period of gestation (Harlow et al. 2002). Reindeer have to cope with a highly variable Arctic climate that limits the availability of food, so the maternal protein stored by the mother in early winter typically contributes up to $96 \%$ of the fetal growth (Barboza and Parker 2008). Fin whales do not hibernate but instead carry out long migrations and commute between warm but low-productivity breeding areas and cool but highly productive feeding areas; this cycle implies that gestation takes place during periods of fasting or scarce feeding (Aguilar 2009). As a consequence, in these capital-breeder species the protein incorporated into the embryo would tend to originate from the mother's protein. This would lead to a trophic enrichment of ${ }^{15} \mathrm{~N}$, the intensity of which will likely be related to the degree of allocation of protein from maternal tissues, a fact that nonetheless does not exclude the potential influence of species-specific variability on $\Delta^{15} \mathrm{~N}$ values (table 2), as Jenkins et al. (2001) suggested.

In contrast with the above scenario, the protein obtained through foraging by an income breeder during reproduction

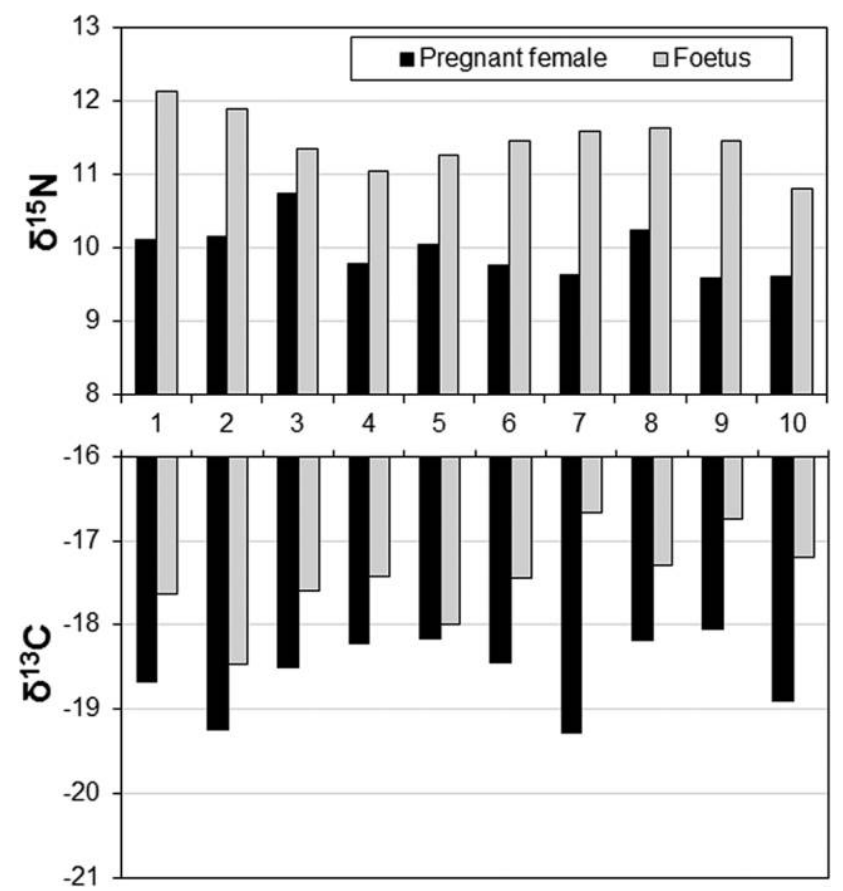

Figure 2. Pairwise comparison of muscle $\delta^{15} \mathrm{~N}$ and $\delta^{13} \mathrm{C}$ values between pregnant North Atlantic fin whale females and their respective fetuses. Numbers in the $X$-axis are the codes of the pregnant females. A color version of this figure is available online. 


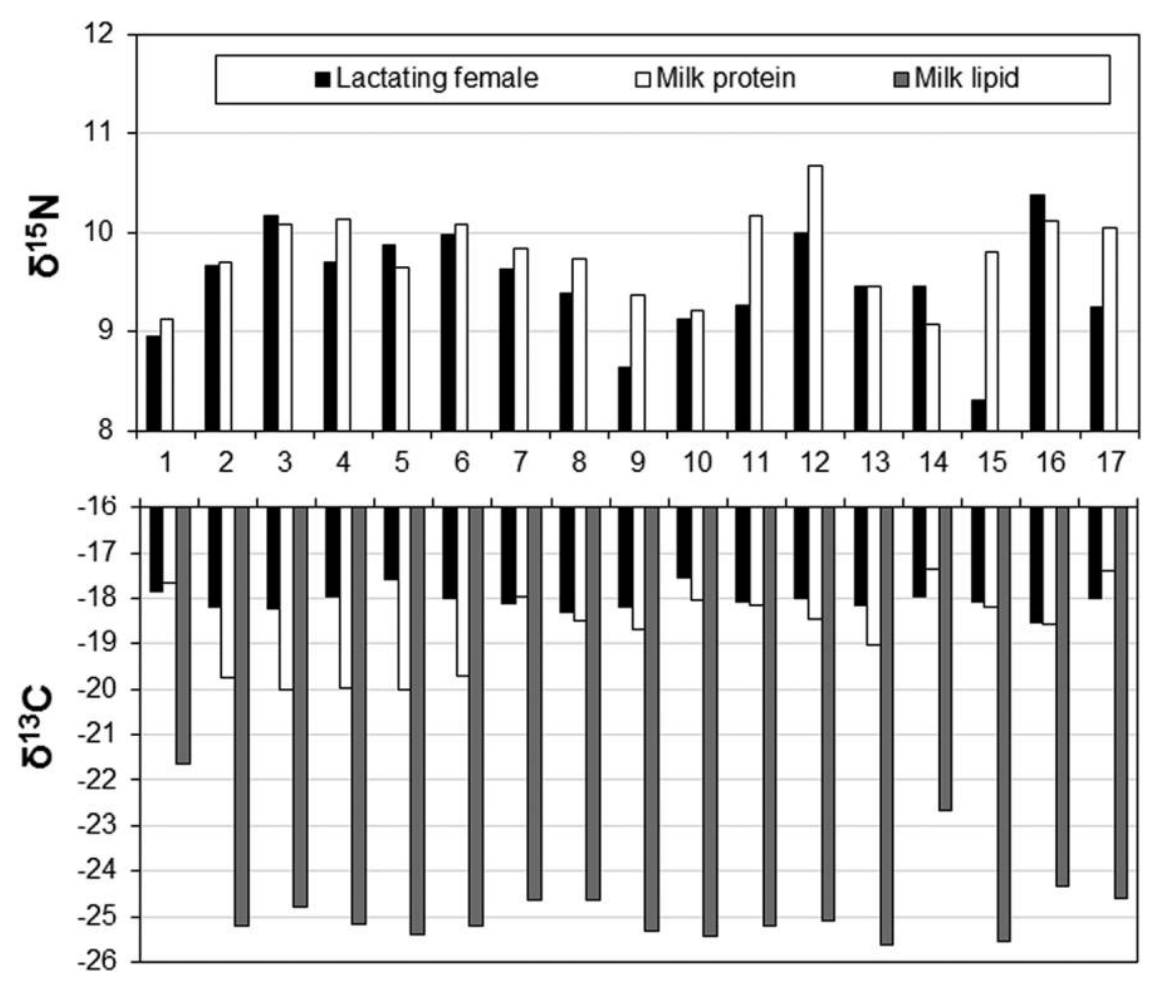

Figure 3. Pairwise comparison of $\delta^{15} \mathrm{~N}$ and $\delta^{13} \mathrm{C}$ values between muscle, milk protein, and milk lipids in North Atlantic lactating fin whales. Numbers in the $X$-axis are the codes of the lactating females analyzed. A color version of this figure is available online.

would be directly incorporated into the embryonic tissues instead of into the female tissues (Stephens et al. 2009), thus avoiding trophic enrichment of ${ }^{15} \mathrm{~N}$. As a consequence, $\Delta \Delta^{15} \mathrm{~N}$ between maternal and fetal tissues is nonexistent, as has been suggested by Dalerum et al. (2007). The northern elephant seal deserves a special mention. This pinniped has been proposed to adopt an intermediate breeding strategy: during gestation, it would behave as an income breeder, that is, it would actively forage, while during its $\sim 26 \mathrm{~d}$ of lactation it would shift to perform as a capital breeder, that is, it would fast from food and water (Costa et al. 1986; Stephens et al. 2009). However, the fact that neonates of this species show some discrimination in $\delta^{15} \mathrm{~N}$ (Habran et al. 2010) may suggest that pregnant females, in addition to directly allocating ingested resources to build fetal tissues, may partly rely on their own protein to complement embryonic development.

With regard to $\delta^{13} \mathrm{C}$ discrimination (hereafter $\Delta^{13} \mathrm{C}$ ), results from previous studies are fewer and less consistent. Among the income breeders, neither Fogel et al. (1989), in humans, nor Jenkins et al. (2001), in nine income-breeder mammal species, found significant discrimination between the fetal or neonatal tissues and the maternal tissues. In capital breeders, results were either inconclusive or inconsistent. Thus, while the results of our study conducted on muscle of fin whales showed a fetal-maternal $\Delta^{13} \mathrm{C}$ of $1.13 \%$, those of Nelson et al. (1998) on collagen from fossil bones of the European cave bear showed a $\Delta^{13} \mathrm{C}$ of $-2.3 \%$, although, for the reasons mentioned above, the latter results should be considered with caution. In the northern elephant seal, which, as mentioned above, is an intermediate income/capital breeder,
Habran et al. (2010) did not find significant $\Delta^{13} \mathrm{C}$. The absence of a clear trend likely has to do with the fact that the effect of trophic level on the $\delta^{13} \mathrm{C}$ value is not as strong as it is in the case of the $\delta^{15} \mathrm{~N}$ value. In mammals, the mean $\Delta^{15} \mathrm{~N}_{\text {tissue-diet }}$ is $3 \%$ o ( $n=89)$, while the $\Delta^{13} \mathrm{C}_{\text {tissue-diet }}$ is only $0.5 \%$ o $(n=95$; Caut et al. 2009), values that have a much milder capacity to trigger differences between mothers and their fetuses. Moreover, the $\delta^{13} \mathrm{C}$ value is highly influenced by the lipid and carbohydrate content of the tissue (Post et al. 2007), a factor that likely contributes to masking or diluting any potential effect of differences in protein allocation or recycling.

Whatever the case, it should be noted that this interpretation, although widespread in comparable previous studies (i.e., Jenkins et al. 2001; Gauthier et al. 2003; Habran et al. 2010), considers only variation in bulk proteins and lipids and that this may be an oversimplification of the actual biochemical changes taking place (King 2000). As mentioned above, there is no doubt that the actual processes are more complex, because many factors, particularly the different biochemical composition of tissues, affect discrimination when the macromolecules are routed from the diet to the reproducing female and her fetus and milk and/or from the reproducing female to her fetus and milk.

\section{Isotopic Discrimination between Muscle and Milk in Lactating Females}

Few previous studies in lactating females have examined the isotope discrimination between body tissues and milk. Those 


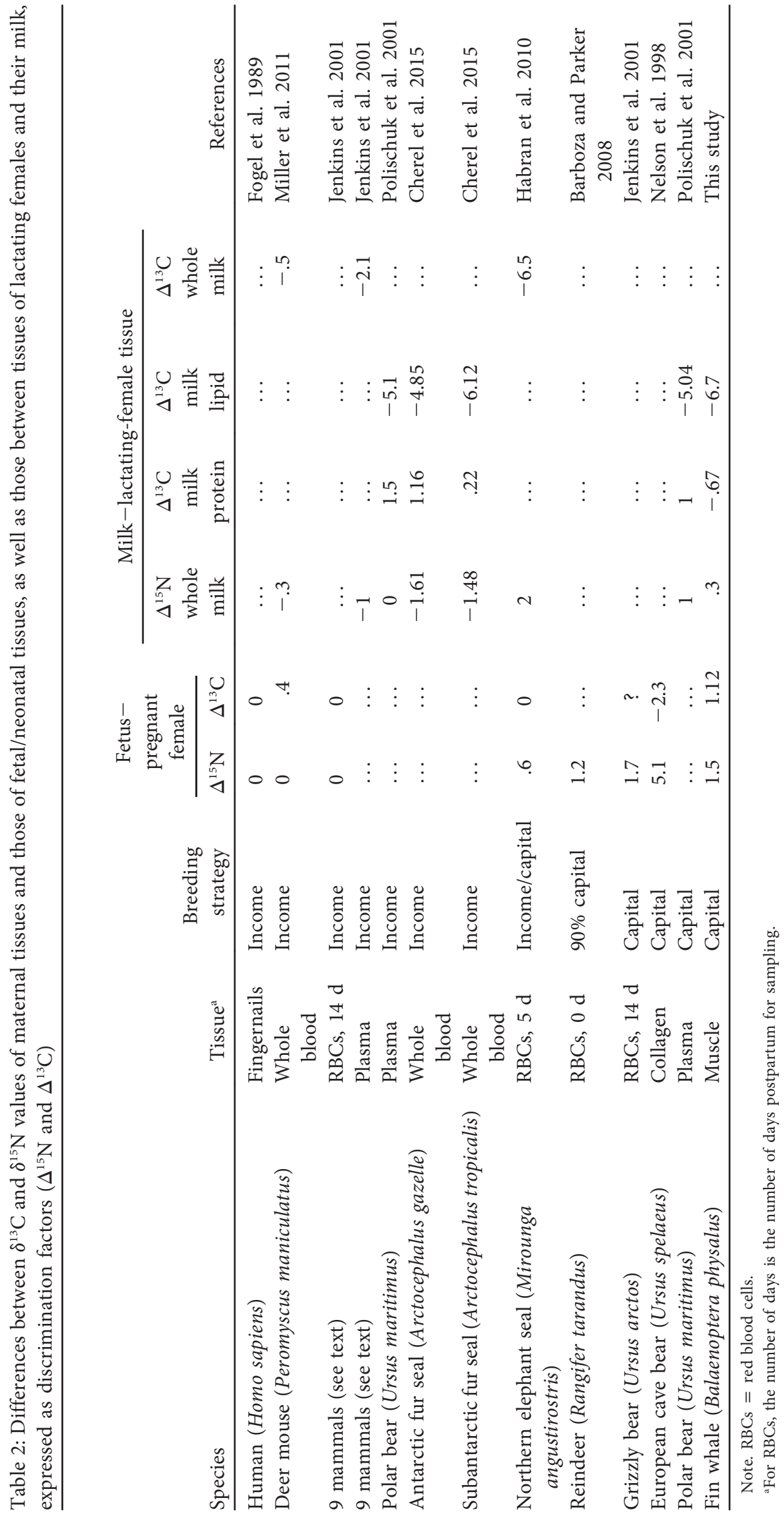

This content downloaded from 161.116.168.092 on May 23, 2018 07:41:51 AM 
available differ from the approach followed in this study in at least two main elements. The first is that, in previous studies, stable isotopes in milk were analyzed without a previous separation of proteins and lipids, while here we did analyze the lipid-free tissue and the lipids separately. This is relevant because lipids are ${ }^{13} \mathrm{C}$ depleted during biochemical discrimination (DeNiro and Epstein 1977), and, since milk is very rich in lipids, the previous studies consequently showed overall very low $\delta^{13} \mathrm{C}$ values in whole milk (i.e., Jenkins et al. 2001; Habran et al. 2010). This effect was indeed confirmed by Stegall et al. (2008), who, studying Steller sea lions, found that $\delta^{13} \mathrm{C}$ values were $5.8 \%$ $\pm 1 \%$ o higher in milk from which lipids had been extracted (i.e., in milk proteins) than in nonextracted (whole) milk. The constituent separation is irrelevant for $\delta^{15} \mathrm{~N}$ values, as lipids have very low nitrogen content $(<0.5 \%)$ and therefore $\delta^{15} \mathrm{~N}$ values correspond almost completely to the protein fraction of the milk.

The second differential element in our research was that the maternal tissue analyzed and compared to the milk was muscle, while in previous studies it was whole blood or blood components such as plasma or RBCs (i.e., Jenkins et al. 2001; Polischuk et al. 2001; Habran et al. 2010; Miller et al. 2011; Cherel et al. 2015). This provides different grounds for comparison because the turnover rate of muscle and whole blood is lower than that of plasma, a tissue that reflects the nitrogen status of only the most recent days or weeks (Phillips and Eldridge 2006; Caut et al. 2011), and also because tissue discrimination differs between tissues following the trend plasma $\sim$ whole blood $>$ muscle $>$ RBCs (Caut et al. 2009).

Despite these differences, when the collective results from these studies on milk $\Delta{ }^{15} \mathrm{~N}$ and $\Delta{ }^{13} \mathrm{C}$ are examined in detail (table 2), they provide evidence for a pattern governed by the strategy followed in the use of energy during reproduction. With regard to nitrogen, lactating females of income breeders show negative $\Delta^{15} \mathrm{~N}$ between their tissues and their milk.

Thus, Jenkins et al. (2001) found in nine income-breeder species a $-1.0 \%$ o $\pm 0.5 \%$ o $\Delta^{15} \mathrm{~N}$ between whole milk and plasma; Miller et al. (2011) found in the deer mouse (Peromyscus maniculatus) a $-0.3 \%$ o $\Delta^{15} \mathrm{~N}$ between whole milk and whole blood; and Cherel et al. (2015) found between the same tissues in two species of fur seals (Arctocephalus gazelle and Arctocephalus tropicalis) a $\Delta^{15} \mathrm{~N}$ of $-1.61 \%$ and $-1.48 \%$, respectively. These negative discrimination values likely reflect the fact that these species derive the nutrients for milk directly from their diet (Miller et al. 2011) thus sparing much metabolic processing.

Contrary to this, capital breeders did show positive $\Delta^{15} \mathrm{~N}$ values between the tissues of lactating females and their milk. Thus, Habran et al. (2010), studying lactating northern elephant seal females, found $\Delta^{15} \mathrm{~N}$ of $2 \%$ in whole milk, as compared to RBCs. This is consistent with the fact that elephant seal females nurse their pups while they fast from food and water (Le Boeuf et al. 1972) and consequently their milk has to be synthesized from body reserves. Polischuk et al. (2001) studied polar bears (Ursus maritimus) and similarly found a $1 \% \Delta^{15} \mathrm{~N}$ in milk proteins, as compared to plasma, in lactating mothers during the periods when they were fasting, but they observed that such discrimina- tion approached 0 when the bears had access to seals for feeding (table 2; Polischuk et al. 2001). Our results, the first of this nature to be obtained in a cetacean, confirm this consistent difference by showing a $0.3 \%$ o $\Delta^{15} \mathrm{~N}$ between muscle and milk protein in lactating fin whales. Unfortunately, the results of Jenkins et al. (2001) on grizzly bears, another capital breeder, could not be examined in this respect because the data of that species were pooled with those from other species that performed as income breeders. The observed positive $\Delta^{15} \mathrm{~N}$ in capital-breeding mammals is likely due to the initial assimilation of nutrients into the females' lean body mass and posterior allocation of proteins to milk (Jönsson 1997), which leads to a preferential incorporation into the milk protein of the ${ }^{15} \mathrm{~N}$ isotope.

However, it is worth noting that the capital breeders' $\Delta^{15} \mathrm{~N}$ values (between $0.3 \%$ and $2 \%$; table 2 ) were overall lower than the commonly accepted trophic shift of 3\%o-5\%o (Caut et al. 2009). The difference may be due to the metabolic pathways followed for milk production from females' lean body mass, which are different from those used for the building up of other tissues from food. Moreover, in the case of the fin whales studied here, the low $\Delta^{15} \mathrm{~N}$ value $(0.3 \%$ ) is also likely to reflect the fact that the lactating females had been sampled after completing their migration and having reached the feeding grounds and were consequently already ingesting food. As a consequence, the $\Delta^{15} \mathrm{~N}$ in these animals was probably low because milk proteins were likely derived in part from maternal reserves and in part from ingested food, as is typical in income-breeder mammals (Stearns 1992). Moreover, previous studies on this species and population have shown that $\delta^{15} \mathrm{~N}$ values in muscle tend to increase during the feeding season (Aguilar et al. 2014), a fact that would also interfere with the tissue values observed.

In results from previous studies in which milk proteins had not been separated from lipids, $\Delta^{13} \mathrm{C}$ was in all cases negative $\left(-0.5 \%\right.$ o to $-6.5 \%$ ). The same happened when $\Delta^{13} \mathrm{C}$ was calculated in the lipid fraction of the milk $(-4.8 \%$ o to $-6.7 \%$; table 2). This study on fin whales and those of Polischuk et al. (2001) on polar bears and Cherel et al. (2015) on fur seals are the only ones in which isotope profiles in milk proteins were calculated. Surprisingly, the results are inconsistent. In fin whales, we found a $-0.67 \% \circ \Delta^{13} \mathrm{C}$ between female milk proteins and muscle, while Polischuk et al. (2001) found a $1 \% 0-1.5 \%{ }_{0} \Delta^{13} \mathrm{C}$ between female milk proteins and plasma in polar bears, and Cherel et al. (2015) found a $0.22 \% 0-1.16 \% \Delta^{13} \mathrm{C}$ between female milk proteins and whole blood. The reasons for this apparent discrepancy are unclear, and this is certainly a field that deserves further studies on other species allowing simultaneous sampling of maternal tissues and milk.

\section{Comparison of Isotope Profiles between \\ Pregnant and Lactating Females}

Studies on the dynamics of stable isotopes in the maternal body tissues during gestation and lactation are equally scant, as compared to those of the issues discussed above. With regard to nitrogen, Fuller et al. (2004) reported a $\delta^{15} \mathrm{~N}$ decrease in human maternal hair during gestation (decrease in $\delta^{15} \mathrm{~N}$ of $0.6 \%$; $P<$ 
0.001) and pointed out that the magnitude of the drop correlated to the baby's birth weight. They associated this decrease with the physiological changes occurring during pregnancy, in particular a progressive reduction in the loss of ${ }^{15} \mathrm{~N}$-depleted urinary nitrogen as pregnant females achieve positive nitrogen balance. In wild horses, Koch (1997) also found a decline that resulted in lower $\delta^{15} \mathrm{~N}$ values in lactating females as compared to nonlactating females or males; however, in this case the author attributed the $\delta^{15} \mathrm{~N}$ decrease to nitrogen-balance perturbations associated with lactation. Consistent with these findings, a study on blood components in northern fur seals Callorhinus ursinus (Kurle 2002) reported $\sim 1 \%$ o higher $\delta^{15} \mathrm{~N}$ values in pregnant females than in lactating females, and one on plasma in polar bears found $\sim 1.9 \%$ o higher $\delta^{15} \mathrm{~N}$ values in pregnant females than in lactating females with cubs of the year (Polischuk et al. 2001). Our results were unclear, and the comparison tests failed to find significant differences in $\delta^{15} \mathrm{~N}$ between pregnant and lactating fin whales. However, the dissimilitude was marginally nonsignificant $(P<$ 0.1 ), a result that probably is more a consequence of the low statistical power of the small sample size than of an actual homogeneity in signatures (Hoem 2008). Thus, pregnant females appeared to have somewhat higher values of $\delta^{15} \mathrm{~N}$ than lactating females, suggesting a slight modification in maternal muscle proteins during gestation or, perhaps, during lactation. It is thus likely that maternal tissues would decrease their $\delta^{15} \mathrm{~N}$ during pregnancy on the same path by which the fetus progressively enriches in ${ }^{15} \mathrm{~N}$, a process that results in a balance in the tissues of the mother-fetus pair.

With regard to carbon, stable-isotope studies are not conclusive. In humans, no significant effect of pregnancy on $\delta^{13} \mathrm{C}$ was observed (Fuller et al. 2004), but Polischuk et al. (2001) reported in polar bear and Kurle (2002) in northern fur seals that $\delta^{13} \mathrm{C}$ values for blood components were higher in pregnant females than in lactating females by $0.65 \%$ and $1.1 \%$, respectively. Conversely, in our study on fin whales, we found that $\delta^{13} \mathrm{C}$ values were significantly lower in pregnant than in lactating females $(P<0.001$; fig. 1$)$, although the difference was very small $\left(\delta^{13} \mathrm{C}_{\text {preg }}-\delta^{13} \mathrm{C}_{\text {lact }}=-0.58 \%\right)$. A possible explanation for the apparent discrepancy is the high fat content $(\approx 60 \%)$ of the whale milk, which would prompt females to employ large part of their own lipid reserves to produce it. As lipids are known to be ${ }^{13} \mathrm{C}$ depleted relative to proteins (DeNiro and Epstein 1977), such a process could account for a relative increase in ${ }^{13} \mathrm{C}$ in muscle proteins of lactating females.

\section{Conclusions}

This study shows that the fetuses of fin whales are enriched compared to their mothers in both ${ }^{15} \mathrm{~N}$ and ${ }^{13} \mathrm{C}$, while, compared to muscle, milk is enriched in ${ }^{15} \mathrm{~N}$ but depleted in ${ }^{13} \mathrm{C}$. Because this pattern is similar to that found in other capital breeders but different from that found in income breeders, the isotopic contrast of bulk tissues in marine mammals and their offspring proves a useful tool to investigate the physiological consequences of breeding strategies. However, final clarification of this issue will be possible only with the application of isotopic analysis of individual amino acids or specific carbon or nitrogen atoms at sites on individual amino acids.

\section{Acknowledgments}

We are indebted to Pilar Rubio and Pilar Teixidor from the Centres Científics i Tecnològics of the University of Barcelona (CCiT-UB) for assistance in the stable-isotope analysis. The study was funded by the Fundació Barcelona Zoo.

\section{Literature Cited}

Aguilar A. 2009. Fin whale, Balaenoptera physalus. Pp. 433-437 in W.F. Perrin, B. Würsig, and J.G.M. Thewissen, eds. Encyclopedia of marine mammals. Academic Press, Amsterdam.

Aguilar A., J. Giménez, E. Gómez-Campos, L. Cardona, and A. Borrell. 2014. $\delta^{15} \mathrm{~N}$ value does not reflect fasting in mysticetes. PLoS ONE 9:e92288. doi:10.1371/journal.pone.0092288.

Barboza P.S. and K.L. Parker. 2008. Allocating protein to reproduction in Arctic reindeer and caribou. Physiol Biochem Zool 81:835-855.

Ben-David M. and E.A. Flaherty. 2012. Stable isotopes in mammalian research: a beginner's guide. I Mammal 93:312-328.

Bond J.C., D. Esler, and K.A. Hobson. 2007. Isotopic evidence for sources of nutrients allocated to clutch formation by harlequin ducks. Condor 109:698-704.

Borrell A., N. Abad-Oliva, E. Gómez-Campos, J. Giménez, and A. Aguilar. 2012. Discrimination of stable isotopes in fin whale tissues and application to diet assessment in cetaceans. $\underline{\text { Rapid }}$ Commun Mass Spectrom 26:1596-1602.

Borrell A., A. Velásquez Vacca, A.M. Pinela, C. Kinze, C.H. Lockyer, M. Vighi, and A. Aguilar. 2013. Stable isotopes provide insight into population structure and segregation in eastern North Atlantic sperm whales. Plos One 8:e82398. doi:10.1371 /journal.pone.0082398.

Caut S., E. Angulo, and F. Courchamp. 2009. Variation in discrimination factors $\left(\Delta^{15} \mathrm{~N}\right.$ and $\left.\Delta^{13} \mathrm{C}\right)$ : the effect of diet isotopic values and applications for diet reconstruction. I Appl Ecol 46: 443-453.

Caut S., S. Laran, E. Garcia-Hartmann, and K. Das. 2011. Stable isotopes of captive cetaceans (killer whales and bottlenose dolphins). LExp Biol 214:538-545.

Cherel Y., K.A. Hobson, and C. Guinet. 2015. Milk isotopic values demonstrate that nursing fur seal pups are a full trophic level higher than their mothers. Rapid Commun Mass Spectrom 29: 1485-1490.

Costa D.P., B.J. Le Boeuf, A.C. Huntle, and C.L. Ortiz. 1986. The energetics of lactation in the northern elephant seal, Mirounga angustirostris. IZool 209:21-33.

Dalerum N., C. Bennett, and T.H. Clutton-Brock. 2007. Longitudinal differences in ${ }^{15} \mathrm{~N}$ between mothers and offspring during and after weaning in a small cooperative mammal, the meerkat (Suricata suricatta). Rapid Commun Mass Spectrom 21:1889-1892. 
DeNiro M.J. and S. Epstein. 1977. Mechanism of carbon isotope fractionation associated with lipid synthesis. Science 197: 261-263.

Festa-Bianchet M., J.M. Gaillard, and J.T. Jorgenson. 1998. Mass- and density-dependent reproductive success and reproductive costs in a capital breeder. Am Nat 152:367379.

Fogel M.L., N. Tuross, and D.W. Owsley. 1989. Nitrogen isotope tracers of human lactation in modern and archeological populations. Pp. 111-117 in Annual Report of the Director of the Geophysical Laboratory, Carnegie Institution. Geophysical Laboratory, Washington, DC.

Folch J., M. Lees, and G.H. Sloane Stanley. 1957. A simple method for the isolation and purification of total lipids from animal tissues. I Biol Chem 226:497-509.

Fuller B.T., J.L. Fuller, N.E. Sage, D.A. Harris, T.C. O'Connell, and R.E.M. Hedges. 2004. Nitrogen balance and $\delta^{15} \mathrm{~N}$ : why you're not what you eat during pregnancy. Rapid Commun Mass Spectrom 18:2889-2896.

Gauthier G., J. Bêty, and K.A. Hobson. 2003. Are greater snow geese capital breeders? new evidence from a stable-isotope model. Ecology 84:3250-3264.

Giménez J., E. Gómez-Campos, A. Borrell, L. Cardona, and A. Aguilar. 2013. Isotopic evidence of limited exchange between Mediterranean and eastern North Atlantic fin whales. Rapid Commun Mass Spectrom 27:1801-1806.

Habran S., C. Debier, D.E. Crocker, D.S. Houser, G. Lepoint, J.M. Bouquegneau, and K. Das. 2010. Assessment of gestation, lactation and fasting on stable isotope ratios in northern elephant seals (Mirounga angustirostris). Mar Mamm Sci 26:880-895.

Harlow H.J., T. Lohuis, G. Grogan, and T.D. Beck. 2002. Body mass and lipid changes by hibernating reproductive and nonreproductive black bears. L Mammal 83:1020-1025.

Hilderbrand G.V., S.D. Farley, C.T. Robbins, T.A. Hanley, K. Titus, and C. Servheen. 1996. Use of stable isotopes to determine diets of living and extinct bears. Can I Zool 74: 2080-2088.

Hobson K.A. 2006. Using stable isotopes to quantitatively track endogenous and exogenous nutrient allocations to eggs of birds that travel to breed. Ardea 94:359-369.

Hobson K.A., B.N. McLellan, and J.G. Woods. 2000. Using stable carbon $\left(\delta^{13} \mathrm{C}\right)$ and nitrogen $\left(\delta^{15} \mathrm{~N}\right)$ isotopes to infer trophic relationships among black and grizzly bears in the upper Columbia River basin, British Columbia. Can I Zool 78:1332-1339.

Hobson K.A. and J.L. Sease. 1998. Stable isotope analyses of tooth annuli reveal temporal dietary records: an example using Steller sea lions. Mar Mamm Sci 14:116-129.

Hobson K.A., J.L. Sease, R.L. Merrick, and J.F. Piatt. 1997. Investigating trophic relationships of pinnipeds in Alaska and Washington using stable isotope ratios of nitrogen and carbon. Mar Mamm Sci 13:114-132.

Hoem J. 2008. The reporting of statistical significance in scientific journals. Demogr Res 18:437-442.
Jenkins S.G., S.T. Partridge, T.R. Stephenson, S.D. Farley, and C.T. Robbins. 2001. Nitrogen and carbon isotope fractionation between mothers, neonates, and nursing offspring. Oecologia 129:336-341.

Jönsson K.I. 1997. Capital and income breeding as alternative tactics of resource use in reproduction. Oikos 78:57-66.

Kelly J.F. 2000. Stable isotopes of carbon and nitrogen in the study of avian and mammalian trophic ecology. Can I Zool 78:1-27.

King J.C. 2000. Physiology of pregnancy and nutrient metabolism. Am J Clin Nutr 7:1218-1225.

Klaassen M., Å. Lindström, H. Meltofte, and T. Piersma. 2001. Ornithology: Arctic waders are not capital breeders. Nature 413:794.

Koch P.L. 1997. Nitrogen isotope ecology of carnivores and herbivores. J Vertebr Paleontol 17(suppl. 3):57A.

- 2007. Isotopic study of the biology of modern and fossil vertebrates. Pp. 99-154 in R. Michener and K. Lajtha, eds. Stable isotopes in ecology and environmental science. Blackwell, Boston.

Kurle C.M. 2002. Stable-isotope ratios of blood components from captive northern fur seals (Callorhinus ursinus) and their diet: applications for studying the foraging ecology of wild otariids. Can I Zool 80:902-909.

Kurle C.M., P.L. Koch, B.R. Tershy, and D.A. Croll. 2014. The effects of sex, tissue type, and dietary components on stable isotope discrimination factors $\left({ }^{13} \mathrm{C}\right.$ and $\left.{ }^{15} \mathrm{~N}\right)$ in mammalian omnivores. Isot Environ Health Stud 50:307-321.

Langin K.M., D.R. Norris, T.K. Kyser, P.P. Marra, and L.M. Ratcliffe. 2006. Capital versus income breeding in a migratory passerine bird: evidence from stable-carbon isotopes. Can I Zool 84:947-953.

Le Boeuf B.J., R.J. Whiting, and R.F. Gantt. 1972. Perinatal behavior of northern elephant seal females and their young. Behaviour 43:121-156.

Lockyer C.H. 1981. Growth and energy budgets of large baleen whales from the Southern Hemisphere. Pp. 379-487 in J. Gordon Clark, ed. Mammals in the seas. Vol. 3. General papers and large cetaceans. Fisheries Series 5. Food and Agriculture Organization, Rome.

- 1984. Review of baleen whale (Mysticeti) reproduction and implications for management. Rep Int Whaling Comm Spec Issue 6:27-48.

Miller J.F., J.S. Millar, and F.J. Longstaffe. 2011. Stable nitrogen and carbon isotope discrimination between juveniles and adults in an income-breeding small mammal (Peromyscus maniculatus). Mamm Biol 76:563-569.

Nelson D.E., A. Angerbjorn, K. Liden, and I. Turk. 1998. Stable isotopes and the metabolism of the European cave bear. Oecologia 116:177-181.

Newsome S.D., M.T. Clementz, and P.L. Koch. 2010. Using stable isotope biogeochemistry to study marine mammal ecology. Mar Mamm Sci 26:509-572.

Newsome S.D., P.L. Koch, M.A. Etnier, and D. Aurioles-Gamboa. 2006. Using carbon and nitrogen isotope values to investigate 
maternal strategies in northeast Pacific otariids. Mar Mamm Sci 22:556-572.

Oftedal O.T. 2000. Use of maternal reserves as a lactation strategy in large mammals. Proc Nutr Soc 59:99-106.

Phillips D.L. and P.M. Eldridge. 2006. Estimating the timing of diet shifts using stable isotopes. Oecologia 147:195-203.

Polischuk S.C., K.A. Hobson, and M.A. Ramsay. 2001. Use of stable-carbon and -nitrogen isotopes to assess weaning and fasting in female polar bears and their cubs. Can I Zool 79:499-511.

Post D.M., C.A. Layman, D.A. Arrington, G. Takimoto, J. Quattrochi, and C.G. Montana. 2007. Getting to the fat of the matter: models, methods and assumptions for dealing with lipids in stable isotope analyses. Oecologia 152:179-189.

Sanpera C. and A. Aguilar. 1992. Modern whaling off the Iberian Peninsula during the 20th century. Rep Int Whaling Comm 42:723-729.
Stearns S.C. 1992. The evolution of life histories. Oxford University Press, Oxford.

Stegall V.K., S.D. Farley, L.D. Rea, K.W. Pitcher, R.O. Rye, C.L. Kester, C.A. Stricker, and C.R. Bern. 2008. The discrimination of carbon and nitrogen isotopes from milk to serum and vibrissae in Alaska Steller sea lions (Eumetopias jubatus). Can I Zool 86:17-23.

Stephens P.A., I.L. Boyd, J.M. McNamara, and A.I. Houston. 2009. Capital breeding and income breeding: their meaning, measurement, and worth. Ecology 90:2057-2067.

Vales D.G., L. Cardona, N.A. García, L. Zenteno, and E.A. Crespo. 2015. Ontogenetic dietary changes in male South American fur seals Arctocephalus australis in Patagonia. Mar Ecol Prog Ser 525:245-260.

Voigt C.C. and F. Matt. 2004. Nitrogen stress causes unpredictable enrichments of ${ }^{15} \mathrm{~N}$ in two nectar-feeding bat species. LExp Biol 207:1741-1748. 